\title{
Optimalisasi Rute Distribusi BBM dengan Penerapan Capacitated Vehicle Routing Problem dan Excel Solver di Kabupaten Magetan
}

\author{
Euis Nurlathifah, Fathin Kusumo Pramesti Pudjiantoro, Naufal Ammar, Wahyudi Sutopo*, dan \\ Yuniaristanto
}

\author{
Program Studi Teknik Industri, Fakultas Teknik, Universitas Sebelas Maret, Jl. Ir. Sutami 36 A Kentingan, \\ Surakarta, 51726, Indonesia \\ *Corresponding author : Wahyudisutopo@staff.uns.ac.id
}

\begin{abstract}
ABSTRAK
Pertamina Fuel Terminal Boyolali MOR IV memiliki tugas untuk mendistribusikan produk BBM yang dihasilkan ke SPBU di Jawa Tengah dan sebagian Jawa Timur. Penelitian ini membahas pendistribusian BBM dari depot ke SPBU di Kabupaten Magetan dengan permintaan BBM sebesar 16 kl, 24 kl, dan 32 kl dengan pemilihan atau penentuan rute distribusi yang tepat sehingga memperoleh ketepatan waktu yang optimal. Tahapan penelitian yang pertama membuat formulasi model masalah capacitated vehicle routing problem (CVRP) menggunakan Excel Solver sebagai metode penyelesaiannya. Lalu tiga kriteria rute mobil tangki dengan kapasitas 16 kl, 24 kl dan 32 kl digunakan untuk menentukan distribusi BBM di Kabupaten Magetan. Hasil simulasi menggunakan software Excel Solver didapatkan rute terpendek untuk mengirimkan BBM ke 11 SPBU yang berada di Kabupaten Magetan dengan menggunakan 1 mobil tangki 24kl dan mobil tangki 32 kl. Dan didapatkan total jarak yang dilaluli oleh semua kendaraan mobil tangki adalah sejauh 2260,6 kilometer sehingga memberikan rute yang lebih baik dari rute yang ada sebelumnya yaitu sejauh 2686,2 kilometer.
\end{abstract}

Kata kunci: CVRP, distribusi, excel solver, rute

\section{Optimization of BBM Distribution Routes by Implementing Capacitated Vehicle Routing Problem and Excel Solver in Magetan}

\begin{abstract}
Pertamina Fuel Terminal Boyolali MOR IV has the duty to distribute fuel products produced to gas stations in Central Java and parts of East Java. This study discusses the distribution of fuel from depots to gas stations in Magetan Regency with fuel demand of $16 \mathrm{kl}, 24 \mathrm{kl}$, and $32 \mathrm{kl}$ by selecting or determining the right distribution route so as to obtain optimal timeliness. The first stage of the research was to formulate a capacitated vehicle routing problem (CVRP) model using Excel Solver as a solution. Furthermore, to determine the distribution of fuel in Magetan Regency with three criteria, namely the tank car route with a capacity of $16 \mathrm{kl}, 24 \mathrm{kl}$ and $32 \mathrm{kl}$. The simulation results using Excel Solver software obtained the shortest route to send fuel to 11 gas stations in Magetan Regency using $124 \mathrm{kl}$ tank truck and $32 \mathrm{kl}$ tank truck. And the total distance obtained by all tanker vehicles is 2260.6 kilometers so that it provides a better route than the previous route, which is 2686.2 kilometers.
\end{abstract}

Keywords: CVRP, distribution, excel solver, route

\section{Pendahuluan}

Fuel Terminal Boyolali MOR IV merupakan salah satu anak perusahaan dari PT. Pertamina (Persero) yang memiliki tugas untuk mendistribusikan produk bahan bakar minyak (BBM) ke SPBU di daerah Jawa Tengah bagian Timur dan Tengah, dan sebagian daerah Jawa Timur bagian barat. Dalam pendistribusian BBM banyak komponen yang harus diperhatikan oleh fuel terminal Boyolali. Komponen tersebut bukan hanya berasal dari dalam perusahaan (fuel terminal Boyolali) tetapi juga dari supplier yang dalam hal ini yaitu PT. Pertamina Refinery Unit IV Cilacap dan retailer yang dalam hal ini yaitu SPBU yang di supply, serta pihak-pihak yang telah bekerja sama dengan fuel Pertamina Boyolali MOR IV, dimana 
semua komponen tersebut membentuk suatu rantai yang disebut dengan rantai pasok atau supply chain.

Proses pendistribusian BBM oleh fuel Terminal Boyolali dimulai dengan pembayaran oleh pihak SPBU yang mekanismenya yaitu prepayment. SPBU melakukan pembayaran melalui bank persepsi. Pembayaran dilakukan dengan menyebutkan data permintaan bahan bakar minyak serta kode unik yang dimiliki oleh masing-masing SPBU. Setelah melakukan pembayaran maka dibuatlah sales order yang kemudian oleh pihak fuel Terminal Boyolali akan membuat loading order. Distribusi BBM sesuai dengan permintaan masing-masing SPBU dan dilakukan satu hari setelah pembayaran dilakukan. Distribusi BBM ini dilakukan dengan menggunakan moda transportasi mobil tangki. Mobil tangki disediakan oleh anak perusahaan Pertamina yaitu PT. Pertamina Patra Niaga. Jumlah mobil tangki yang tersedia saat ini adalah 104 unit yang memiliki daya angkut $2.432 \mathrm{kl}$, dimana fuel Terminal Boyolali akan melakukan pembayaran sewa untuk mobil tangki tersebut setiap bulannya.

Fuel Terminal Boyolali melakukan distribusi ke 245 SPBU yang terdiri dari daerah Salatiga dan Ungaran, Sragen, Surakarta, Klaten, Karanganyar, Sukoharjo, Boyolali, Ngawi, Purwodadi, Magetan, Wonogiri, dan Pacitan. BBM didistribusikan menggunakan mobil tangki dari fuel terminal Boyolali sesuai dengan permintaan masingmasing SPBU. Untuk pendistribusian dari fuel terminal Boyolali ke masing-masing SPBU sesuai dengan permintaan setiap SPBU dengan menggunakan mobil tangki. Rute setiap mobil tangki akan ditentukan dari kapasitas mobil tangki dan permintaan dari SPBU yang akan dituju. Gambar 1. merupakan gambar alur proses dari penyaluran BBM dari depot (fuel terminal Boyolali) ke SPBU-SPBU.

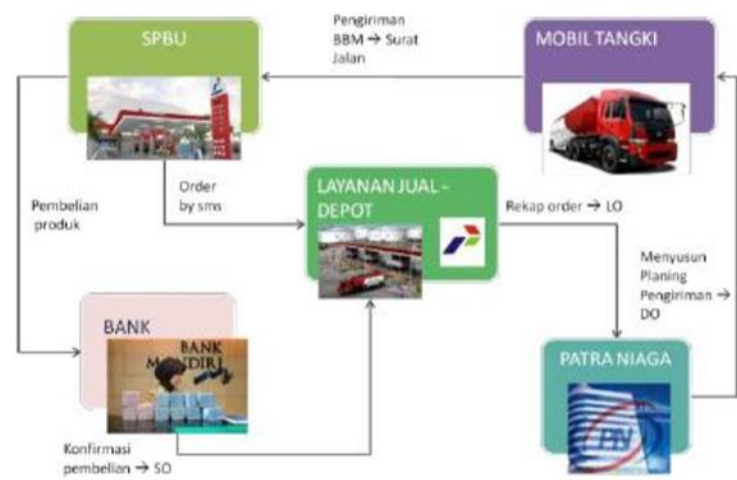

Gambar 1. Alur Proses Penyaluran BBM

Permasalahan yang sering terjadi pada proses pendistribusian adalah terdapat banyak tempat yang harus dikunjungi dalam sistem distribusi (node) dan diharuskan tidak terjadi pengulangan, kemudian harus kembali ke titik semula, sehingga rute yang harus ditempuh akan menjadi banyak kemungkinannya. Permasalahan tersebut dikenal dengan istilah vehicle routing problem (VRP). Salah satu solusi yang layak untuk CVRP deterministik untuk menemukan tur utama (Frenstorm dan steiner, 2020)

Penelitian Gadegaard dkk (2020) mengusulkan formulasi berukuran polinomial baru dari masalah symmetric capacitated vehicle routing problem. Menurut Prins, dkk (2009) masalah perutean kendaraan tersebar luas dalam distribusi dan logistik. VRP umumnya terdiri dari masalah penugasan, masalah salesman keliling dan masalah jalur kendaraan (Wang dan Lu, 2010). VRP adalah optimalisasi kombinatorial dan masalah pemrograman yang berusaha melayani sejumlah pelanggan dengan armada kendaraan (R.N. Mohd, 2015). .VRP adalah salah satu yang paling sering mengalami masalah optimasi di bidang logistik, yang bertujuan untuk meminimalkan biaya operasi transportasi oleh fluks kendaraan yang beroperasi dari pangkalan yang disebut Depot (E. Gunes, 2017). Fluks kendaraan yang dimaksud adalah aliran dari setiap kendaraan yang beroperasi dari depot. VRP memiliki tujuan meminimalkan jarak dan biaya tetap yang berhubungan dengan penggunaan kendaraan, meminimalkan banyaknya kendaraan yang dibutuhkan untuk memenuhi kebutuhan konsumen, menyeimbangkan rute 
dalam hal waktu dan muatan, serta meminimalkan pinalti sebagai akibat dari kurangnya pelayanan seperti keterlambatan pengiriman, dll (Cetin dan Gencer, 2015). Toth dan Vigo (2002) menyatakan bahwa VRP memiliki beberapa jenis permasalahan utama yaitu Capacitated Vehicle Routing Problem (CVRP), Vehicle Routing Problem with Pick Up and Delivery (VRPPD), Distance Constrained Vehicle Routing Problem (DCVRP), Vehicle Routing Problem with Multiple Depot (VRPMD), Split Delivery Vehicle Routing Problem (SDVRP), dan Vehicle Routing Problem with Time Windows (VRPTW). Sebuah penelitian mengusulkan FA hibrida baru, yang disebut CVRP-FA, untuk memecahkan masalah rute perutean kendaraan berkapasitas (Altabeeb dkk, 2019).

Capacitated Vehicle Routing Problem (CVRP) yaitu masalah optimasi untuk menentukan rute dengan biaya minimal (minimum cost), banyaknya kendaraan (vehicles) dengan kapasitas tertentu yang homogen (homogeneus fleet), yang melayani sejumlah customer dengan jumlah permintaan telah diketahui sebelum proses pendistribusian berlangsung (Gunawan, dkk, 2012). Tujuan utama VRP untuk melayani permintaan pelanggan yang telah ditentukan dengan rute kendaraan biaya mínimum dengan titik mulai dan berakhir di sebuah depot. Vehicle Routing Problem (VRP) yang mengurangi biaya saat mengantarkan tepat waktu, yaitu VRP Time Windows (VRPTW), telah menjadi isu populer dalam penelitian optimisasi. Di sisi lain, jika distribusi tergantung pada kapasitas kendaraan, itu disebut Capacitated VRP (CVRP) (Jose, dkk, 2011). Lubis, dkk (2016) menyatakan bahwa penerapan VRP dalam angkutan sampah di Kota Bandung dapat meningkatkan volume angkutan sampah yang terangkut setiap harinya sehingga menyisakan timbulan sampah minimum di setiap Tempat Pengakutann sampah (TPS).

Masalah perutean kendaraan muncul dalam banyak situasi praktis, termasuk pengiriman barang ke pelanggan, penjemputan dan pengangkutan sampah kota ke tempat pembuangan akhir, penjabaran rencana perjalanan untuk kendaraan listrik dengan pemberhentian di stasiun pengisian ulang, pengangkutan orang dengan pengurangan mobilitas, dan perbaikan peralatan di berbagai rumah (Souza Neto dan Pureza, 2016). Suatu rute yang optimal adalah rute yang memenuhi berbagai kendala operasional, yaitu memiliki total jarak dan waktuperjalanan yang ditempuh terpendek dalam memenuhi permintaan konsumen sertamenggunakan kendaraan dalam jumlah yang terbatas (Yuniarti dan Astuti, 2013). Iori dan Martello (2010) memperluas pendekatan penelitian yang relatif baru untuk memecahkan masalah pemuatan kendaraan dan masalah rute kendaraan dalam satu upaya. Penelitian ini mempertimbangkan pengemasan dua dan tiga dimensi ke dalam kendaraan. Vehicle Routing Problem (VRP), yang dikenal sebagai depot tunggal, banyak kendaraan, masalah rute routing, adalah pendekatan klasik yang digunakan dalam aplikasi transportasi dan alokasi sumber daya (Laporte, 2009). Pendekatan VRP standar berbeda dari pendekatan Multi Traveling Salesman Problem (MTSP) dalam hal kapasitas kendaraan diketahui dan terbatas, dan setiap node menampung permintaan deterministik pada rute. VRP standar dapat diperluas untuk mendukung waktu rute maksimum untuk setiap kendaraan armada. Pendekatan yang tepat telah ditentukan untuk VRP. Namun, seperti halnya penerapan pendekatan TSP, seringkali waktu pemrosesan yang diizinkan membatasi jenis metodologi solusi yang digunakan. Masalah perutean kendaraan klasik (VRP) bertujuan untuk menemukan serangkaian rute dengan biaya minimal (menemukan jalur terpendek, meminimalkan jumlah kendaraan, dll) memulai dan mengakhiri rute di depot, sehingga permintaan semua node yang diketahui terpenuhi.

Hadhiatma dan Purbo (2017) menyatakan bahwa selain untuk membuat sebuah solusi aplikasi untuk kasus pendistribusian barang dari gudang ke beberapa toko pada PT CircleK regional Yogya, juga untuk menguji sejauh mana 
tingkat akurasi hasil rute terpendek dari algoritma semut untuk penyelesaian kasus tersebut. Vehicle Routing Problem diterapkan menggunakan metode Nearest Neighbor untuk mengoptimalkan rute pendistribusian. Pengumpulan data meliputi data permintaan dan jarak antar lokasi. Distance matrix disusun berdasarkan data jarak antar lokasi. Nicola dkk (2019) menggunkaan model estimasi berbasis regresi yang memberikan prediksi cepat untuk jarak tempuh dalam masalah traveling salesman problem (TSP), capacitated vehicle routing problem with Time Windows (CVRP$\mathrm{TW}$ ), dan multi-region multi-depot pickup and delivery problem (MR-MDPDP). Asymmetric Capacitated Vehicle Routing Problem (ACVRP), menggabungkan beberapa konsep heuristik dengan formulasi compact-integer linear programming (MILP) (Leggieri dan Haouari, 2018). Metode Nearest Neighbor dipergunakan untuk merancang rute berdasarkan jarak terdekat berikutnya (Amri, dkk, 2014). Rute optimal di fuel terminal MOR IV dianalisa menggunakan Algoritma Genetika. Rute tersebut dikatakan optimal jika rute yang terpilih adalah rute dengan jalur terpendek (Fadhlurrahman dan Binatari, 2017). Pistikopoulos, dkk (2011) membahas Capacitated Vehicle Routing Problem(CVRP) yang mengingat armada kendaraan kapasitansi homogen sehingga bertujuan untuk merancang serangkaian rute perjalanan pulang pergi dengan biaya terendah untuk melayani sejumlah pelanggan dengan permintaan yang diketahui. Metode yang bisa digunakan adalah dengan menggunakan Vehicle Routing Problem (VRP). Metode ini nantinya akan memberikan routing yang optimal sehingga jarak ataupun waktu yang dihasilkan adalah yang terpendek ataupun tercepat, dengan demikian penggunaan bahan bakar menjadi lebih e sien dan mengurangi gas $\mathrm{CO} 2$ (Jaramillo, 2010). Chandra dan Setiawan (2018) menyatakan bahwa mengaplikasikan VRP untuk mempercepat distribusi produk dan meminimalkan penggunaan bahan bakar. VRP termasuk dalam non-polynominal hard (NPhards), yang umumnya menggunakan pendekatan heuristik untuk menemukan solusi
(Slamet, dkk, 2014). Rute yang optimal dapat ditentukan menggunakan Algoritma Diferensial Evolusi untuk menghitung rute terpendek untuk setiap agensi dan memaksimalkan penggunaan kendaraan menggunakan koordinat dan permintaan agensi (Saputra dkk, 2018). Sianipar dkk (2017) menggunakan metode Clark and Wreight Saving Heuristic untuk menentukan kombinasi rute yang tepat, sehingga dapat meminimasi biaya dengan mengurangi jarak yang ditempuh oleh armada dan lama waktu pengiriman setiap kendaraan serta mengurangi kesalahan pelayanan seperti pengiriman yang tertunda. Saraswati dkk (2017) membentuk model Capacitated Vehicle Routing Problem pada permasalahan rute distribusi harian Solopos wilayah Kartasura-Klaten dengan algoritma sweep.

Subramanian (2012) menyebutkan bahwa tujuan dari diikutsertakannya faktor kendaraan yang heterogen adalah agar diketahui penggunaan kendaraan yang tepat sesuai dengan rute dan demand yang sesuai dengan pelanggan agar didapat biaya yang paling minimal dan tidak boros penggunaan sumber daya kendaraan yang dimiliki. Pertimbangan perbedaan kapasitas kendaraan yang berbeda ini dengan pertimbangan bahwa suatu perusahaan pasti mempunyai kendaraan yang memiliki kapasitas berbeda. Masalah Routing Vehicle Pengiriman Terpisah dengan kendala pemuatan tiga dimensi (3L-SDVRP) menggabungkan rute kendaraan dan pemuatan tiga dimensi dengan kendala pengemasan tambahan (Bortfeldt, dan Yi, 2020). Penelitian Garzon-Garnica dkk (2015) Automated Data Acquisition (ADA) untuk Masalah Rute Kendaraan Berkapasitas Besar (CVRP). Penelitian Akpinar (2016) menyajikan algoritma hybrid baru yang mengeksekusi algoritma pencarian lingkungan besar dalam kombinasi dengan construction mechanism of the ant colony optimization algorithm (LNS-ACO) untuk masalah capacitated vehicle routing problem (CVRP). Poonthalir dkk (2020) menggunakan Hybrid Particle Swarm Optimization (HPSO) dan rute biaya minimum yang diperoleh 
ditingkatkan menggunakan operator pertukaran lokal untuk meminimalkan emisi. Hasil penelitian Altabeeb (2019) menunjukkan bahwa CVRP-FA memiliki tingkat konvergensi yang cepat dan akurasi komputasi yang tinggi. Masalah perutean kendaraan kluster-lunak (SoftCluVRP) memperluas masalah perutean kendaraan berkapasitas klasik dengan satu kendala tambahan (Hintsch dan Irnich, 2020). Hannan dkk (2018) mengusulkan algoritma Particle Swarm Optimization (PSO) yang dimodifikasi dalam model Capacitated Vehicle-Routing Problem (CVRP) untuk menentukan pengumpulan limbah dan solusi optimalisasi rute terbaik.

Masalah rute kendaraan memerlukan menemukan rute optimal dari terminal awal ke semua tujuan yang ditentukan sedemikian rupa sehingga permintaan di tujuan terpenuhi dan jarak total yang ditempuh oleh kendaraan pengiriman diminimalkan (Jakara et al, 2019). Tujuan penelitian ini adalah meminimumkan jarak tempuh dari depot ke setiap SPBU tujuan dengan kapasitas mobil tangki yang tersedia. Dalam penelitian ini menggunakan aplikasi excel dalam menyelesaikan program linier, Excel merupakan program pengolah lembar kerja Microsoft yang berada dalam satu paket dengan office. Solver adalah fasilitas bawaan excel yang memungkinkan pengguna untuk menyelesaikan kasus-kasus optimalisasi bukan hanya model linier (Siswanto dan Erlangga, 2007). Penelitian Erdogan (2017) memperkenalkan VRP Spreadsheet Solver, alat berbasis Excel open source untuk menyelesaikan banyak varian Vehicle Routing Problem (VRP).

\section{Metodologi}

Penelitian ini dilakukan untuk pengoptimalan rute pendistribusian BBM dengan penerapan capacitated vehicle routing problem dan software excel spreadsheet solver di Kabupaten Magetan. Capacitated Vehicle Routing Problem (CVRP) adalah masalah optimisasi kombinatorial klasik yang diajukan banyak heuristik, relaksasi, dan algoritma yang tepat (Letchford dan Gonzalez, 2019). Penerapan model CVRP mengacu pada model acuan yaitu model yang digunakan (Fadhlurrahman dan Binatari, 2017). Dengan menggunakan CVRP menunjukkan bahwa algoritma yang diusulkan sangat kompetitif dan sangat efisien untuk optimalisasi tujuan gabungan dari rute kendaraan (Mulloorakam dan Nidhiry, 2019)

Terdapat beberapa tahap dilakukan dalam mencapai tujuan penelitian, diantaranya yang dapat dilihat pada Gambar 2 .

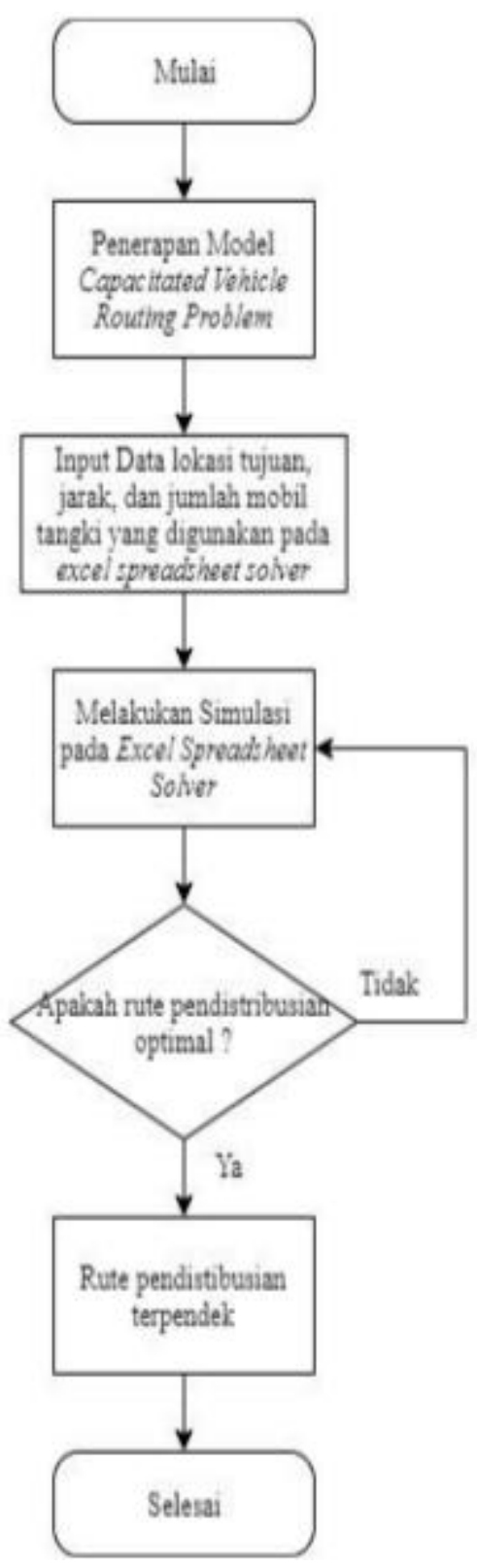

Gambar 2. Flowchart Metodologi Penelitian

Dalam penelitian ini, untuk tercapainya tujuan penelitian yang dilakukan yaitu mendapatkan rute pendistribusian 
terpendek (optimal) dengan penerapan capacitated vehicle routing problem dan excel spreadsheet solver yang memiliki langkahlangkah dalam pengerjaannya yaitu yang pertama, melakukan penerapan model CVRP sesuai acuan yang dipilih, dilanjutkan dengan penginputan data-data yang diperlukan untuk penyelesaian dengan excel spreadsheet solver yaitu data lokasi tujuan, jarak, dan jumlah mobil tangki yang digunakan serta kapasitas mobil tangki yang tersedia. Setelah melakukan penginputan data maka akan dilakukan simulasi oleh excel spreadsheet solver yang akan menghasilkan rute pendistribusian yang akan dilakukan oleh masing-masing mobil tangki. Jika sudah mendapatkan rute pendistribusian yang optimal yaitu dengan jarak rute pendistribusian terpendek maka hasil sudah dapat digunakan sebagai usulan rute yang akan dilakukan saat pendistribusian ke kabupaten Magetan. Jika rute pendistribusian belum optimal maka akan dilakukan simulasi kembali oleh excel spreadsheet solver sampai mendapatkan rute pendistribusian yang optimal yaitu jarak rute pendistribusian terpendek untuk setiap mobil tangki. Sehingga dapat digunakan sebagai usulan rute yang akan dilakukan saat pendistribusian ke kabupaten Magetan.

\section{Hasil dan Pembahasan 3.1. Pengumpulan Data}

Penelitian ini memiliki permasalahan yang terdiri dari depot dan 11 pelanggan yaitu SPBU yang harus dituju. Pelanggan/SPBU memiliki permintaan BBM yang tidak melebihi 32kl karena kapasitas mobil tangki maksimal 32kl. Berikut adalah jarak antara depot dengan SPBU beserta alamat SPBU yang harus dituju:

Tabel 1. Daftar Jarak Depot ke SPBU dan Alamat SPBU Pemesan BBM

\begin{tabular}{|c|c|c|c|}
\hline No & $\begin{array}{c}\text { NO } \\
\text { SPBU }\end{array}$ & $\begin{array}{c}\text { Jarak } \\
(\mathrm{km})\end{array}$ & Alamat \\
\hline 1 & 5463301 & 129 & $\begin{array}{l}\text { SPBU Pertamina 54.633.01, Jl. Gub. Suryo, Dusun Krajan, Baron, Kec. Magetan, } \\
\text { Kabupaten Magetan, Jawa Timur } 63319\end{array}$ \\
\hline 2 & 5463302 & 132 & $\begin{array}{l}\text { SPBU Pertamina 54.633.02, JL. Letjen MT Haryono, RT 003/11, Dusun } \\
\text { Karanganyar, Kepolorejo, Kec. Magetan, Kabupaten Magetan, Jawa Timur } 63311\end{array}$ \\
\hline 3 & 5463303 & 130 & $\begin{array}{l}\text { SPBU Pertamina 54.633.03, Jl. Raya Takeran, Genengan, Kawedanan, Sekolanan, } \\
\text { Genengan, Magetan, Kabupaten Magetan, Jawa Timur } 63382\end{array}$ \\
\hline 4 & 5463305 & 119 & $\begin{array}{l}\text { SPBU Pertamina 54.633.05, Dusun II, Malang, Kec. Maospati, Kabupaten } \\
\text { Magetan, Jawa Timur } 63392\end{array}$ \\
\hline 5 & 5463310 & 134 & $\begin{array}{l}\text { SPBU Pertamina 54.633.10 magetan kota, Jl. Magetan Sarangan, Candi Kidul, } \\
\text { Candirejo, Kec. Magetan, Kabupaten Magetan, Jawa Timur } 63319\end{array}$ \\
\hline 6 & 5463311 & 125 & $\begin{array}{l}\text { SPBU Pertamina 54.633.11 sukomoro, JL Raya Sukomoro, No. 170, Bulu, Bulu } \\
\text { Timur, Bulu, Kec. Magetan, Kabupaten Magetan, Jawa Timur } 63395\end{array}$ \\
\hline 7 & 5463317 & 133 & $\begin{array}{l}\text { SPBU Pertamina 54.633.17 Klagen Gambiran, Jl. Nasional 20, Sanggrahan, } \\
\text { Klagen Gambiran, Maospati, Magetan Regency, East Java } 63161\end{array}$ \\
\hline 8 & 5463306 & 113 & $\begin{array}{l}\text { SPBU Pertamina 54.633.06 karangrejo, Jl. Raya Maospati - Ngawi, Bulusari, } \\
\text { Patihan, Kec. Karangrejo, Kabupaten Magetan, Jawa Timur } 63395\end{array}$ \\
\hline 9 & 5463308 & 116 & $\begin{array}{l}\text { SPBU Pertamina } 54.633 .08 \text { barat magetan, Jl. Mangge, Candi, Mangge, Kec. Bar., } \\
\text { Kabupaten Magetan, Jawa Timur } 63395\end{array}$ \\
\hline 10 & 5463312 & 126 & $\begin{array}{l}\text { SPBU Pertamina 54.633.12, Jl. Raya Bendo, Belotan, Bendo, Kabupaten Magetan, } \\
\text { Jawa Timur } 63384\end{array}$ \\
\hline 11 & 5463316 & 134 & $\begin{array}{l}\text { SPBU No 54,633,16, Jl. Raya Gorang Gareng, Tugu, Mojopurno, Ngariboyo, } \\
\text { Kabupaten Magetan, Jawa Timur } 63351\end{array}$ \\
\hline
\end{tabular}




\subsection{Penerapan Model CVRP}

Jalur yang digunakan untuk mendistribusikan BBM adalah jalur yang dilewati oleh Armada Mobil Tangki Pertamina. Jalur tersebut akan dikategorikan sebagai rute. Rute pendistribusian mobil tangki akan digunakan dalam pembuatan ilustrasi model rute pendistribusian BBM dengan simulasi Excel Solver. Jumlah kendaraan yang akan digunakan memiliki kapasitas $q=$ $\{16,24,32\}$ dan setiap SPBU memiliki permintaan $d=\{16,24,32\}$ serta setiap $i, j € E$ memiliki jarak yang ditempuh yang didefinisikan sebagai $\mathrm{c}_{\mathrm{ij}}$ dimana jarak Depot ke SPBU dan sebaliknya simetris $c_{i j}=c_{j i}$. Didefinisikan untuk setiap $(i, j) €, I \neq 0, j \neq 0$ dan untuk setiap mobil tangki $k$ didefinisikan dengan variable $x_{i j k}=$ pendistribusian dari $i \mathrm{ke}$ $j$ dengan mobil tangki $k$.

Fungsi tujuan:

minimasi $=z \sum_{k=1}^{3} \sum_{i=1}^{11} \sum_{j=1}^{11} c_{i j} x_{i j k}$

Batasan-batasan model:

$\sum_{k=1}^{3} \sum_{j=1}^{11} x_{i j k}=1, \quad \forall i \in V$

$\sum_{i=1}^{11} \sum_{j=1}^{11} x_{i j k} \leq 32, \forall k \in V$

$\sum_{j=1}^{11} x_{o j k}=1, \quad \forall k \in K$

$\sum_{i=0}^{11} x_{i j k}-\sum_{j=0}^{11} x_{j i k}=0, \quad \forall k \in K$

$\sum_{j=1}^{11} x_{i o k}=1, \quad \forall k \in K$

$x_{i j k} \in\{0,1\}, \forall i, j \in V, \forall k \in K$
Batasan (2) memastikan bahwa setiap SPBU dikunjungi tepat satu kali oleh satu kendaraan, batasan (3) menyatakan permintaan semua agen dalam satu rute tidak melebihi kapasitas kendaaraan yaitu 32kl, batasan (4) menyatakan setiap rute berawal dari depot, batasan (5) menyatakan bahwa setiap kendaraan yang mengunjungi satu titik pasti akan meninggalkan titik tersebut, batasan (6) menyatakan setiap rute berakhir di depot dan batasan (7) menyatakan variabel keputusan merupakan variabel biner.

\subsection{Hasil Simulasi Excel Solver}

Penelitian ini menentukan rute distribusi BBM di Kabupaten Magetan dengan permintaan 16kl, 24kl dan 32kl. Tabel SPBU dan permintaan BBM dapat dilihat pada Tabel 3 dan peta lokasi SPBU dapat dilihat pada Gambar 3.

Tabel 2. Permintaan SPBU di Kabupaten

Magetan

\begin{tabular}{ccc}
\hline No. & SPBU & Permintaan $(\mathrm{kl})$ \\
\hline 1 & 5463301 & 16 \\
2 & 5463302 & 16 \\
3 & 5463303 & 24 \\
4 & 5463305 & 16 \\
5 & 5463310 & 16 \\
6 & 5463311 & 24 \\
7 & 5463317 & 32 \\
8 & 5463306 & 24 \\
9 & 5463308 & 24 \\
10 & 5463312 & 24 \\
11 & 5463316 & 16 \\
& & \\
\hline
\end{tabular}




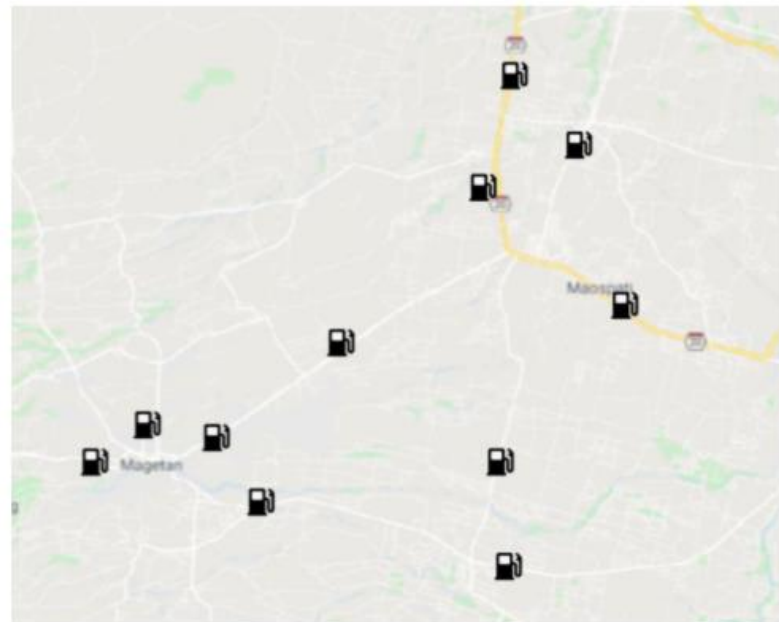

Gambar 3. Peta Lokasi SPBU di Kabupaten Magetan

Tabel 3. Hasil Simulasi Excel Solver

\begin{tabular}{ccccccc}
$\begin{array}{c}\text { Stop } \\
\text { Count }\end{array}$ & $\begin{array}{c}\text { Location } \\
\text { name }\end{array}$ & $\begin{array}{c}\text { Location } \\
\text { ID }\end{array}$ & Latitude (y) & Longitude (x) & $\begin{array}{c}\text { Distance } \\
\text { travelled }\end{array}$ & Load \\
\hline 0 & Depot & 0 & -7.535258 & 110.667588 & 0 & 24 \\
1 & 5463306 & 8 & -7.550086 & 111.425295 & 113 & 0 \\
2 & Depot & 0 & -7.535258 & 110.667588 & 226 & 24 \\
3 & 5463303 & 3 & -7.682523 & 111.418187 & 356 & 0 \\
4 & Depot & 0 & -7.535258 & 110.667588 & 486 & 0 \\
\hline
\end{tabular}

Dari Tabel 3, hasil simulasi Excel Solver didapatkan jarak minimum yang ditempuh untuk mobil tangki $24 \mathrm{kl}$ sejauh 486 kilometer dan untuk kendaraan mobil tangki 32kl sejauh 1774,6 kilometer. Dengan mobil tangki $24 \mathrm{kl}$ melakukan rute dari Depot5463306-depot-5463303-depot dan mobil tangki 32kl melakukan rute dari depot5463316-5463301-depot-5463302-5463310depot-5463311-depot-5463312-depot5463305-depot5463317-depot-5463308depot. Jumlah mobil tangki yang digunakan yaitu 0 mobil tangki 16kl, 1 mobil tangki $24 \mathrm{kl}$ dan 1 mobil tangki 32kl. Sehingga total jarak yang dilaluli oleh semua kendaraan mobil tangki adalah sejauh 2260,6 kilometer. Adapun rute yang digunakan Fuel Terminal Boyolali MOR IV dengan jumlah SPBU yang sama memiliki total jarak 2686,2 kilometer. Hal ini terlihat bahwa penggunaan Excel Solver memberikan rute yang lebih baik dari rute yang ada sebelumnya sehingga dapat meningkatkan efektivitas operasional Fuel Terminal.

\section{Kesimpulan}

Penelitian ini telah membuktikan hasil perhitungan dalam menentukan jumlah mobil yang optimal dalam melakukan pengisian tangki SPBU. Jumlah mobil tangki yang digunakan yaitu 0 mobil tangki 16kl, 1 mobil tangki 24kl dan 1 mobil tangki 32kl

Dari hasil simulasi menggunakan software Excel Solver diperoleh kesimpulan bahwa penggunaan Excel Solver dapat menyelesaikan permasalahan optimalisasi distribusi BBM khususnya Capacitated Vehicle Routing Problem (CVRP) dengan baik. Dengan dilakukan simulasi menggunakan software Excel Solver didapatkan rute terpendek untuk mengirimkan BBM ke 11 SPBU yang berada di Kabupaten Magetan dengan menggunakan 1 mobil tangki $24 \mathrm{kl}$ dan mobil tangki $32 \mathrm{kl}$ didapatkan rute terpendek untuk mobil tangki 24kl sejauh 486 
kilometer yang melewati rute dari Depot5463306-depot-5463303-depot dan untuk mobil tangki 32kl sejauh 1774,6 kilometer yang melewati rute dari depot-54633165463301-depot-5463302-5463310depot5463311-depot-5463312-depot-5463305depot-5463317-depot-5463308-depot. Dan didapatkan total jarak yang dilaluli oleh semua kendaraan mobil tangki adalah sejauh 2260,6 kilometer sehingga memberikan rute yang lebih baik dari rute yang ada sebelumnya yaitu sejauh 2686,2 kilometer.

Saran pada penelitian selanjutnya untuk bisa memperhatikan biaya armada dan waktu kirim ke tiap SPBU agar memberikan hasil yang maksimal dan mampu memberikan dampak positif yang lebih besar bagi perusahaan.

\section{Daftar Pustaka}

Amri, M., Rahman, A., dan Yuniarti, R. (2014). Penyelesaian Vehicle Routing Problem dengan Menggunakan Metode Nearest Neighbor (Studi Kasus: MTP Nganjuk Distributor PT. Coca Cola). Jurnal Rekayasa dan Manajemen Sistem Industri, Vol. 2, No. 1, hal. 36-45.

Cetin, S. and Gencer, C. (2015) A Heuristic Algorithm for Vehicle Routing Problems with SimultaneousPick-Up and Delivery and Hard Time Windows. Open Journal of Social Sciences, Vol. 3, hal. 35-41.

Chandra, A., dan Setiawan, B. (2018). Optimasi Jalur Distribusi dengan Metode Vehicle Routing Problem (VRP). Jurnal Manajemen Transportasi dan Logistik, Vol. 5, No. 2, hal. 105-116.

Erdogan, G. (2017). An open source spreadsheet solver for vehicle routing problems. Computers dan Operations Research, Vol. 84, hal. 62-72.

Fadhlurrahman, M. G., dan Binatari, N. (2014). Optimalisasi Rute Distribusi Bbm di Terminal BBM Boyolali MOR IV menggunakan Algoritma Genetika. Prosiding Matematika dan Pendidikan Matematika UNY, hal. 107-113. (Yogyakarta, 11 November 2017)
Gunawan, G., Maryati, I., dan Wibowo, H. K. (2012). Optimasi penentuan rute kendaraan pada sistem distribusi barang dengan ant colony optimization. Prosiding Seminar Nasional Teknologi Informasi dan Komunikasi Terapan, hal. 163-168. (Semarang, 23 Juni 2012).

Hadhiatma, A., dan Purbo, A. (2017). Vehicle Routing Problem Untuk Distribusi Barang Menggunakan Algoritma Semut. Prosiding Seminar Nasional Teknologi dan Informatika, hal. 139-145. (Kudus, 25 Juli 2017).

Iori, M., dan Martello, S. (2010). Routing problems with loading constraints. TOP Journal of the Spanish Society of Statistics and Operations Research, Vol. 18, No. 1, hal. 4-27.

Jakara, M., Skrinjar, J. P. dan Brnjac, N. (2019). Vehicle Routing Problem - Case Study On LogisticsCompany In Croatia. International Journal for Traffic and Transport Engineering, Vol. 9 No. 4, hal. $456-470$

Jaramillo, J.R. (2010). The green single vehicle routing problem. Myrtle Beach, SC: SE INFORMS Annual Meeting.

Jose, C. S., Haider, A. B., Rui, B., dan Alexandre, S. (2011). A multi objective approach to solve capacitated vehicle routing problems with time windows using mixed integer linear programming. International Journal of Advanced Science and Technology, Vol. 28, hal. 1-8.

Laporte, G. (2009). Fifty years of vehicle routing. Transportation Science, Vol. 43 No. 4, hal. 408-416.

Lubis, H. A. R., Maulana, A., dan Frazila, R. B. (2016). Penerapan Konsep Vehicle Routing Problem dalam Kasus Pengangkutan Sampah di Perkotaan. Journal of Civil Engineering, Vol.23, No. 3, hal. 213-222.

Pistikopoulos, E. N., Georgiadis, M. C., dan Kokossis, A. (2011). 21st European Symposium on Computer Aided Process Engineering, Vol. 29, Elsevier

Prins, C., Labadi, N., dan Reghioui, M. (2009). Tour splitting algorithms for 
vehicle routing problems. International Journal of Production Research, Vol. 47, No.2, hal. 507-535.

Razali, N. M. (2015). An efficient genetic algorithm for large scale vehicle routing problem subject to precedence constraints. Procedia-Social and Behavioral Sciences, Vol. 195, hal. 1922-1931.

Saputra, I. W. Hisjam, M., Sutopo, W. (2018). Optimization of Distribution Channel Vehicle Routing Problem with Time Windows using Differential Evolution Algorithm: A Case Study in Newspaper Industry. Proceedings of the International Conference on Industrial Engineering and Operations Management Bandung, Indonesia, March 6-8, 2018

Saraswati, R., Sutopo, W., Hisjam, M. (2017). Penyelesaian Capacitated Vechile Routing Problem dengan Menggunakan Algoritma Sweep Untuk Penentuan Rute Distribusi Koran : Studi Kasus. Jurnal Manajemen Pemasaran, Vol. 11, No. 2, Oktober 2017 Sianipar, M., Fu'ani, D., Sutopo, W., Hisjam, M. (2017). Penentuan Rute Kendaraan Menggunakan Metode Clark And Wright Saving Heuristic (Studi Kasus : Pt. Sinar Sosro). Performa (2017) Vol. 16, No.2: 143-151

Siswanto, D., dan Erlangga, M. S. (2007). Operations Research, Jilid 1. Jakarta: Penerbit Erlangga.

Slamet, A. S., Siregar, H. H., dan Kustiyo, A. (2014). Vehicle routing problem (VRP) dengan algoritma genetika pada pendistribusian sayuran dataran tinggi. Journal of Agroindustrial Technology, Vol. 24, No. 1, hal. 1-10.

Souza Neto, J. F. D., dan Pureza, V. (2016). Modeling and Solving a Rich Vehicle Routing Problem For The Delivery Of Goods in Urban Areas. Pesquisa Operacional, Vol. 36, No. 3, hal. 421-446.

Subramanian, A., Penna, P. H. V., Uchoa, E., dan Ochi, L. S. (2012). A hybrid algorithm for the heterogeneous fleet vehicle routing problem. European Journal of Operational Research, Vol. 221, No. 2, hal. 285-295.
Toth, P., dan Vigo, D. (Eds.). (2002). The vehicle routing problem. Society for Industrial and Applied Mathematics.

Wang, C. H., dan Lu, J. Z. (2009). A hybrid genetic algorithm that optimizes capacitated vehicle routing problems. Expert Systems with Applications, Vol. 36 No. 2, hal. 2921-2936.

Yuniarti, R. dan Astuti, M. (2013). Penerapan Metode Saving Matrix Dalam Penjadwalan dan Penentuan Rute Distribusi Premium Di SPBU Kota Malang. Jurnal Rekayasa Mesin, Vol. 4, No. 1, hal. 17-26.

Altabeeb, A.M., Mohsen, A.M., Ghallab, A. 2019. An improved hybrid firefly algorithm for capacitated vehicle routing problem. Applied Soft Computing, Volume 84, November 2019, 105728

Frenstorm, F., Steiner, T.A. 2020. A constant approximation algorithm for the uniform a priori capacitated vehicle routing problem with unit demands. Information Processing Letters, Volumes 159160, July 2020, 105960

Letchford, A.N., Gonzalez J. S. 2019. The Capacitated Vehicle Routing Problem: Stronger bounds in pseudo-polynomial time. European Journal of Operational Research, Volume 272, Issue 1, 1 January 2019, Pages 24-31

Mulloorakam, A.T., Nidhiry, N.M. 2019. Combined Objective Optimization for Vehicle Routing Using Genetic Algorithm. Materialstoday: proceedings Volume 11, Part 3, 2019, Pages 891-902

Nicola, D., Vetschera, R., Dragomir, A. 2019. Total distance approximations for routing solutions. Computers and Operations Research, Volume 102, February 2019, Pages 67-74

Bortfeldt, A., Yi, J. 2020. The Split Delivery Vehicle Routing Problem with threedimensional loading constraints. European Journal of Operational Research, Volume 282, Issue 2, 16 April 2020, Pages 545-558

Poonthalir, G., Nadarajan, R., Kumar, M. S. 2020. Hierarchical optimization of green 
routing for mobile advertisement vehicle. Journal of Cleaner Production, Volume 258, 10 June 2020, 120661

Hintsch, T., Irnich, S. 2020. Exact solution of the soft-clustered vehicle-routing problem. European Journal of Operational Research, Volume 280, Issue 1, 1 January 2020, Pages 164-178

Gadegaard, S. L., Lysgaard. J. 2020. A symmetry-free polynomial formulation of the capacitated vehicle routing problem. Discrete Applied Mathematics

Leggieri, V., Haouari, M. 2018. A matheuristic for the asymmetric capacitated vehicle routing problem. Discrete Applied Mathematics, Volume 234, 10 January 2018, Pages 139-150

Akpinar, S. 2016. Hybrid large neighbourhood search algorithm for capacitated vehicle routing problem. Expert Systems with Applications, Volume 61, 1 November 2016, Pages 28-38

Erdogan, G. 2017. An open source Spreadsheet Solver for Vehicle Routing Problems. Computers and Operations Research, Volume 84, August 2017, Pages 62-72

Hannan, M. A., Akhtar, M., Begum. R.A., Basri, H., Hussain, A., Scavino, E. 2018. Capacitated vehicle-routing problem model for scheduled solid waste collection and route optimization using PSO algorithm. Waste Management, Volume 71, January 2018, Pages 31-41

Garazon-Garnica, E. A., Cruz-Benitez, D. P., Badillo-Valenzuela, O. D., SanchezPartida, D., Martinez-Flores, J. L. 2015. Automated Data Acquisition for a Large Scale Capacitated Vehicle Routing Problem. IFAC-Papers OnLine Volume 48, Issue 3, 2015, Pages 1393-1398 